\title{
Human Resource Development-Policies and Practices in Urban Co-operative Credit Banks in Belagavi District ${ }^{\#}$
}

\author{
M. S. Patil ${ }^{*}$ and H.Y. Kamble ${ }^{2}$ \\ 'Assistant Professor \& Head, Department of Commerce, Bhaurao Kakatkar College, Club Road, Camp, Belagavi, Karnataka, India \\ ${ }^{2}$ Professor \& Chairman, Dean, Faculty of Commerce Rani Channamma University, Bhutaramanhatti, Belagavi, Karnataka, India
}

\begin{abstract}
The efficiency of the employees in urban co-operative banks is influenced by the HRD policies adopted in these banks. These policies may be favourable or unfavorable to employees. The favorable HRD policies help the urban co-operative banks to increase the profitability and employee satisfaction. Due to politicization and lack of professionalization in managerial leadership in co-operatives, the employees have been neglected. There is hidden grievance in the minds of employees in these banks. Since, employees in urban co-operative banks are not organized, they cannot raise the voice collectively against the management. This paper aims at studying HRD policies followed by management of different urban co-operative banks in Belagavi district. It also includes the analysis of perceptions of employees in respect of HRD policies pursued by these banks. For this purpose, all 36 urban co-operative banks in Belagavi district have been sełected. They have in total 109 brahches. 61 branches have been selected as sample on convenient random sampling basis. For selection of sample of employees, census method has been adopted. Sample of employees include 370 respondents consisting of 116 officers and 254 clerks. The close ended questionnaires regarding the HRD policies and practices were prepared by using Likert Type Five Point Summated Scale. These questionnaires were canvassed and personally administered. The questionnaires relating to HRD policies were obtained from management of all urban co-operative banks in the district. The questionnaires relating to HRD practices were served to all employees of selected branches in all the urban co-operative banks. Statistical techniques like tabulation, graphical representation, pie chart, mean, standard deviation, chi-square test, etc. have been used. The analysis is presented in two sections namely the extent of usage of HRD policies and the effectiveness of HRD practices as perceived by the officers and clerks. The collected data was organized, coded and analysed using the SPSS. To measure the level of satisfaction about HRD policies, percentage and mean score have been used. Mean and standard deviation are calculated for the group of officers, group of clerks and total employees for different HRD policies. To study the relation between the level of satisfaction of employees about HRD policies, chi-square test has been used. Chi-square test is conducted for biveriate table to test the independence of the level of employment (officers and clerks) and the levels of response for each HRD policy. Since data is qualitative in nature and sample size is more than 30, Karl Pearson's chi square test is used for analysis. The p-value is calculated on the basis of chi square test. The inferences have been drawn to test the independence of perceptions on HRD policies and the level of employment.
\end{abstract}

Keywords: HRD policies, Perceptions, Officers, Clerks

\footnotetext{
*Email:m_patil1061@rediffmail.com

"Revised and modified version of the paper, presented in the $5^{\text {th }}$ International Conference on "Managing HR at the workplace, SDMIMD, December 2016.
} 


\section{Introduction}

The burning challenges in the globalized economy include formulating HRD policies which satisfy both organizational and individual objectives. In the service sector like banking, insurance, etc. human resources play a predominant role in successful delivery of the service. In banking industry, the sector adopting socialist pattern is co-operative sector. The urban co-operative banks have emerged to avoid the exploitation of people by money lenders. This purpose has been achieved by the banks. Nevertheless, the human resource in these banks remained neglected area. The need has been felt by the researcher to analyze the HRD policies followed in these banks and the perceptions of employees thereon.

\section{Statement of the Problem}

The performance of the urban co-operative banks depends on their profitability. In fact, the profitability of these banks, depends on the employees working in the organization. If employees are satisfied, motivated and empowered, possibility of inerease in banking business is more. The efficiency of employees is influenced by the HRD policies. Several committees were appointed by Central as well as State Governments to look into the problems of co-operatives and to give recommendations. But no committee is appointed to study the problems of employees working in co-operatives. In this sector, the employees are not having favorable opinion about the approach of management in respect of HRD policies. Further, due to politicization and lack of professionalization in managerial leadership in cooperatives, the employees have been neglected. There is hidden grievance in the minds of employees in these banks. Hence, it was thought fit to examine this problem in urban co-operative banks through this study.

\section{Profile of the Study Area, Study Units and Respondents}

Belagavi district is based in North Karnataka having ten talukas. It is surrounded by the borders of Goa and Maharashtra. It is a multi-lingual district where Kannada, Marathi, Konkani and Urdu languages are spoken. The district has a very good rain history. The army and airforce training centres have been established in the district considering the demography of the district. The district has second highest population in the state. Three major rivers are flowing in the district viz., the Krishna, the Malaprabha and the Ghatprabha. South western area of the district is occupied by thick forest known as the Western Ghats, which is the part of world heritage site. There are 239 commercial banks and 108 regional rural banks in the district. There are 36 urban co-operative banks in Belagavi district. They have 109 branches. Three banks are mahila banks and two banks are managed by downtroddens. Majority of the banks are established in Belagavi city. Two urban co-operative banks have completed 100 years. There is no scheduled bank in the district. The respondents include 370 employees consisting of 116 officers and 254 clerks. The gender wise classification includes 310 (84\%) male employees and $60(16 \%)$ female employees. $232(63 \%)$ employees are graduates. 247 (67\%) employees are from commerce field. 306 (83\%) employees are computer literate. 333 (90\%) employees are married.

\section{4.}

- To study the HRD policies followed in urban cooperative banks in study area.

- To study the perceptions of officers and clerks relating to HRD policies.

- To compare the perceptions of officers and clerks on HRD policies.

- To offer suggestions to management in the light of the findings of the study.

\section{Research Methodology}

There are 36 urban co-operative banks in Belagavi district. All banks have been selected for the study. They have in total 109 branches. For selection of sample of employees, census method has been adopted. Sample of employees include 370 respondents consisting of 116 officers and 254 clerks. The close ended questionnaires regarding the HRD policies and practices were prepared by using Likert type five point summated scale. Total number of employees are 910 consisting of 244 officers, 449 clerks and 217 sub staff. For the 
purpose of this study, officers and clerks working in all urban co-operative banks have been considered. Out of 244 officers, 116 officers have responded and out of 449 clerks, 254 clerks have responded. To study the relation between the level of satisfaction of employees about HRD policies, chi-square test has been used. The p-value is calculated on the basis of chi square value.

\section{Review of Literature}

Krishnaveni \& Deepa, (2011), claimed that while implementing HRD policies, organizations should focus not only training programmes but they should also give importance to career planning, employee participation and transparent compensation for employees. Sonali, (2012), studied the necessity of re-engineering of HR practices to gain competitive advantage. The study emphasized the creation of sense of belongingness among employees and participation thereof in decision making process of the organization. Parikshit and Anuj, (2012), examined status of structuring of HRD climate and subsystems in Indian public sector. The study revealed that good HRD policies bring conducive environment for the development of the employees and the organization. Shetty (2011), studied the role of HRM in value creation in co-operative banks. The study indicated that the value creation and employee satisfaction are related to each other. Omondi, et al., (2011), have studied the adoption of extent of adoption of strategic human resource management practices among commercial banks in Kenya. In this study, some factors which discouraged the adoption of human resource development practices have been recognized.

Singh, (2005), found that in public sector, the HRD policy and management philosophy are not related to each other. But in private sector, the HRD policies consider management philosophy. Purohit, (2013), revealed that formal training has been given more importance in post privatization period than that in pre- privatization period. The expectations of organizations in case of recruitment, educational level of candidates have increased after privatization. Sivaprakasam (1993), made an attempt to study the organisational set up for personnel management functions in Central Co-operative Banks in Tamil Nadu. It was also found that there is no systematic plan for recruitment and selection. There was no scientific performance appraisal system to evaluate the performance of the employees. Kumar, (2003), conducted the study to analyze the impact of motivation and morale on employee's behavior and organizational efficiency in the banking sector. It is fount that employees are motivated by pay package, incentives and recognition. It is suggested in this study that there is need for more decentralization of authority and decision-making power. The good work and incentives should be recognized for better performance. Job rotation is to be considered as the most importance measure to increase motivation physical facilities, promotional policies should be favourable to employees.

\section{HRD Policies in Urban Co-operative Banks}

HRD policies exist in 22(61\%) urban co-operative banks. 22 urban co-operative banks authorize directors for framing HRD policy. 17 urban co-operative banks inform these policies by holding meeting of employees. 29 urban co-operative banks (81\%) review the HR policy periodically. 28 urban co-operative banks (78\%) have their formal recruitment policy. The recruitment in 35 urban-o-operative banks is done through direct recruitment. Newspaper advertisement is the source of direct recruitment for 30 banks. 33 banks prefer candidate from local area. 6 banks give preference to $\mathrm{SC} /$ $\mathrm{ST} / \mathrm{OBC}$ candidates in selection procedure. 28 banks $(78 \%)$ have training policy to train employees. But 8 banks (22\%) do not have training policy. 11 banks determine the training needs of employees by getting the recommendation of higher authority. 6 banks determine the training needs of employees by analyzing job performance. 11 banks analyze the job requirement and determine the training needs of employees. The promotion policy is made known to employees by 33 banks. 30 banks promote employees on the basis of only seniority. 3 banks promote employees on the basis of only merit. 33 banks prepare and display the seniority list of employees. 28 banks have written transfer policy and 8 banks do not have such policy. 25 banks communicate the transfer policy to employees. Remaining 11 banks do not inform employees about the transfer policy. 12 banks transfer employees due to shift in the workload. 4 banks consider the family 
Table 1. Comparative perceptions of employees on HRD policies

\begin{tabular}{|c|c|c|c|c|c|c|c|}
\hline S. No. & Perceptions regarding & Cadre & Total & Mean & $x^{2}$ & $\mathrm{P}$ & Inference \\
\hline \multirow[t]{2}{*}{1} & Consideration of employee opinion in HRD policies & Officers & 116 & 2.26 & 2.1899 & 0.7009 & NS \\
\hline & & Clerks & 252 & 2.46 & & & \\
\hline \multirow[t]{2}{*}{2} & Communication of HRD policies to all employees & Officers & 116 & 2.09 & 6.8085 & 0.1464 & NS \\
\hline & & Clerks & 253 & 2.41 & & & \\
\hline \multirow[t]{2}{*}{3} & Fairness and impartiality in recruitment process & Officers & 116 & 3.47 & 7.0889 & 0.1313 & NS \\
\hline & & Clerks & 253 & 3.23 & & & \\
\hline \multirow[t]{2}{*}{4} & Reliability of selection process & Officers & 116 & 3.72 & 10.4851 & 0.0330 & $S$ \\
\hline & & Clerks & 253 & 3.38 & & & \\
\hline \multirow[t]{2}{*}{5} & Scientific selection process for selecting employees & Officers & 116 & 3.33 & 9.2240 & 0.0557 & NS \\
\hline & & Clerks & 253 & 2.93 & & & \\
\hline \multirow[t]{2}{*}{6} & Relationship of training to work in the bank & Officers & 116 & 3.62 & 14.9329 & 0.0048 & VS \\
\hline & & Clerks & 253 & 3.22 & & & \\
\hline \multirow[t]{2}{*}{7} & Knowledge and skill as the focus of the training & Officers & 115 & 3.80 & 12.2103 & 0.0159 & S \\
\hline & & Clerks & 253 & 3.37 & & & \\
\hline \multirow[t]{2}{*}{8} & Addressing competency gap by training programme & Officers & 116 & 3.40 & 10.2267 & 0.0368 & $S$ \\
\hline & & Clerks & 253 & 3.00 & & & \\
\hline \multirow[t]{2}{*}{9} & Proper assessment of training needs & Officers & 116 & 3.41 & 5.2013 & 0.2673 & NS \\
\hline & & Clerks & 253 & 3.17 & & & \\
\hline \multirow[t]{2}{*}{10} & Fairness of the salary payment to employees & Officers & 116 & 2.29 & 6.6515 & 0.1555 & NS \\
\hline & & Clerks & 253 & 2.58 & & & \\
\hline \multirow[t]{2}{*}{11} & Favourable work environment in the bank & Officers & 116 & 3.54 & 11.5419 & 0.0211 & $S$ \\
\hline & & Clerks & 253 & 3.19 & & & \\
\hline \multirow[t]{2}{*}{12} & Rewarding employees showing good performance & Officers & 116 & 2.53 & 11.3140 & 0.0233 & $S$ \\
\hline & & Clerks & 253 & 2.24 & & & \\
\hline 13 & Promotion based on need and rewards to employees & Officers & 116 & 3.47 & 21.4310 & 0.0003 & HS \\
\hline 14 & Evaluation of emplo & & 116 & 3.33 & & 0.0280 & S \\
\hline \multirow[t]{2}{*}{15} & Informing career opportunities to employees & Officers & 114 & 3.26 & 6.464 & 0.1671 & NS \\
\hline & & Clerks & 253 & 2.92 & & & \\
\hline \multirow[t]{2}{*}{16} & Promotion to accept challenges & Officers & 116 & 3.46 & 5.8633 & 0.2096 & NS \\
\hline & & Clerks & 253 & 3.15 & & & \\
\hline \multirow[t]{2}{*}{17} & Fast track promotions to high performing employees & Officers & 116 & 2.29 & 2.5914 & 0.6283 & NS \\
\hline & & Clerks & 253 & 2.47 & & & \\
\hline \multirow[t]{2}{*}{18} & Promotion based on performance & Officers & 116 & 2.46 & 13.6600 & 0.0085 & S \\
\hline & & Clerks & 253 & 2.39 & & & \\
\hline \multirow[t]{2}{*}{19} & Promotion of employees on the basis of seniority & Officers & 116 & 3.66 & 0.06919 & 0.9994 & NS \\
\hline & & Clerks & 253 & 3.55 & & & \\
\hline \multirow[t]{2}{*}{20} & Giving time to adjust with the promoted position & Officers & 116 & 3.42 & 12.0943 & 0.0167 & $S$ \\
\hline & & Clerks & 253 & 3.02 & & & \\
\hline \multirow[t]{2}{*}{21} & Employee transfer as per needs of the bank & Officers & 110 & 3.94 & 5.5192 & 0.2380 & NS \\
\hline & & Clerks & 243 & 3.67 & & & \\
\hline 22 & Transfer to place right person in right place & Officers & 110 & 3.35 & 8.7063 & 0.0689 & NS \\
\hline & & Clerks & 243 & 3.12 & & & \\
\hline 23 & Matching of salary with duty and responsibility & Officers & 116 & 2.51 & 4.3352 & 0.3625 & NS \\
\hline & & Clerks & 253 & 2.43 & & & \\
\hline 24 & Rewarding efficient employees with incentives & Officers & 116 & 2.32 & 19.3997 & 0.0007 & VS \\
\hline & & Clerks & 253 & 2.36 & & & \\
\hline 25 & Sufficient retirement benefits to employees & Officers & 116 & 2.30 & 4.0586 & 0.3981 & NS \\
\hline & & Clerks & 253 & 2.47 & & & \\
\hline
\end{tabular}

Source : Field survey

* $\mathrm{SD}=$ Strongly disagree, $\mathrm{D}=$ Disagree, $\mathrm{N}=$ Neutral, $\mathrm{A}=$ Agree, $\mathrm{SA}=$ Strongly agree NS=Not Significant, S=Significant, VS=Very Significant, HS=Highly Significant Degrees of freedom $(\mathrm{m}-1)(\mathrm{n}-1)=4$, Level of significance $=0.05$

Mean as per Likert scale $=3$, The calculated mean is rounded off to nearest number. 
problems of employees and transfer employees. 25 banks have policy of transferring employees from one branch to another. 3 banks do not have such policy. 21 banks give advance notice to employees about their transfer. 7 banks transfer employees without giving advance notice to employees about their transfer. The performance of employees is appraised periodically in 30 banks. 28 banks appraise their performance for determining the employees to be promoted. 32 banks have their own salary structure. 30 banks provide house rent allowance, 26 banks provide medical allowance. 34 banks give bonus to employees. 2 banks do not give bonus to employees. 34 banks provide provident fund. 30 banks provide gratuity. 16 banks provide pension. 34 banks make provident fund contribution whereas 2 banks do not make provident fund contribution. 15 banks provide incentives to employees for acquiring additional qualification. 21 banks do not give such incentive. Out of total banks, 23 banks provide to employees advance against salary but 13 banks do not provide such advance. 9 banks provide special incentive to the employee for outstanding work. 27 banks do not provide such incentives. $\mathbf{B} 4$ banks provide the loans to employees at concessional rates.

\section{Analysis and Interpretation}

\subsection{Consideration of Opinion of Employees in Framing HRD Policies}

The means of officers and clerks being 2.26 and 2.46 indicate that both officers and clerks are of the opinion that their opinion is not considered in framing HRD policies. The chi-square value in this case is 2.1899 . The $p$ value 0.7009 which is calculated on the basis of chi square with 4 degrees of freedom is higher than the assumed level of significance i.e., 0.05. It indicates that there is no significant difference of opinion among the officers and clerks in respect of consideration of employee opinion in framing HRD policies.

\subsection{Proper Communication of HRD Policies}

The means of officers and clerks being 2.09 and 2.41 reveal that both officers and clerks believe that the
HRD policies are not properly communicated to all the employees. The chi-square value in this case is 6.8085 . The $p$ value 0.1464 which is calculated on the basis of chi square with 4 degrees of freedom is higher than the assumed level of significance i.e., 0.05. Hence, there is no significant difference of opinion among the officers and clerks regarding proper communication of HRD policies by the bank to all the employees.

\subsection{Fairness and Impartiality in Recruitment}

The means of officers and clerks are 3.47 and 3.23. Hence, both officers and clerks have neutral opinion regarding fairness of the recruitment. The chi-square value in this case is 7.0889 . The $p$ value 0.1313 which is calculated on the basis of chi square with 4 degrees of freedom is higher than the assumed level of significance i.e., 0.05. It reveals that the officers and clerks do not have significant difference of opinion on the fairness and impartiality in case of recruitment.

\subsection{Reliability and Systematic Approach to Selection Process}

The mean values of officers and elerks being 3.72 and 3.38 indicate that officers believe in reliability in selection process but clerks show neutral approach. The chi square value is 10.4851 and the $p$ value calculated on the basis of chi square and 4 degrees of freedom is 0.0330 . The $p$ value is lesser than assumed level of significance i.e., 0.05 . Hence, the opinion of officers is significantly different from the opinion of clerks in respect of reliability and systematic approach to selection process.

\subsection{Scientific Selection Process}

The mean values of perceptions of officers and clerks being 3.33 and 2.93 reflect that both the officers and clerks have neutral opinion about the use of scientific selection process in selection of employees. The chi square value calculated is 9.2240 and $p$ value calculated on the basis of chi square and 4 degrees of freedom is 0.0557 . Since $p$ value is more than 0.05 , the assumed level of significance, the officers and clerks do not have significant difference of opinion about the selection based on scientific selection process. 


\subsection{Relation of Training to the Work}

The average perceptions of officers and clerks being 3.62 and 3.22 respectively indicate that officers have positive opinion and clerks have neutral opinion in this case. The chi square value is 14.9329 and $p$ value in this case based on 4 degrees of freedom is 0.0048 . Since the $p$ value is much lesser than the assumed level of significance, the perceptions of officers and clerks regarding the relation of training and the work differ very significantly.

\subsection{Focus of Training}

The average perceptions of officers and clerks being 3.80 and 3.37 respectively indicate that officers have positive opinion and clerks have neutral opinion in this case. The chi square value is 12.2103 and $p$ value in this case based on 4 degrees of freedom is 0.0159 . Since the $\mathrm{p}$ value is lesser than the assumed level of significance, the perceptions of officers and clerks regarding the focus of training on knowledge, skill and attitude development differ significantly.

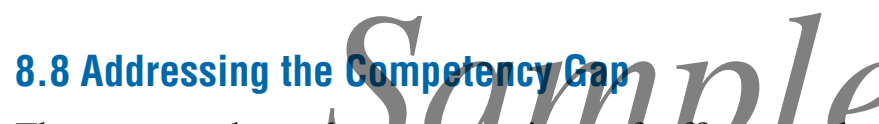

The mean values about perceptions of officers and clerks being 3.40 and 3.00 respectively. It indicates that majority of the officers and clerks have neutral opinion in this case. The chi square value in this case is 10.2267 and the $p$ value based on 4 degrees of freedom is 0.0368 . Since, $p$ value is less than the assumed level of significance, there is significant difference among officers and clerks in respect of the competency gap addressed by the training programmes.

\subsection{Proper Assessment of Training Needs}

The mean values of perceptions of officers and clerks being 3.41 and 3.17 indicate that the officers as well as clerks show neutral attitude in case of the proper assessment of training needs. The chi square value in this case is 5.2013 and the $p$ value based thereon at 4 degrees of freedom is 0.2673 . Since the $p$ value is more than 0.05 , the assumed level of significance, the perceptions of officers and clerks in respect of proper assessment of training needs do not differ significantly.

\subsection{Fairness of Salary to Employees}

The mean values of perceptions of officers and clerks being 2.29 and 2.58 indicate that the officers perceive that salary is not fair as compared to what others are paid. The clerks show neutral attitude in case of the fairness of payment of salary. The chi-square value in this case is 6.6515 and the $p$ value based thereon at 4 degrees of freedom is 0.1555 . Since the $p$ value is more than 0.05 , the assumed level of significance, the perceptions of officers and clerks in respect of fairness of payment of salary do not differ significantly.

\subsection{Work Environment in the Bank}

The average perceptions of officers and clerks being 3.54 and 3.19 respectively indicate that officers agree that the work environment in the bank is favourable for accomplishment and clerks have neutral opinion in this case. The chi square value is 11.5419 and $p$ value in this case based on 4 degrees of freedom is 0.0211 . Since the $p$ value is lesser than the assumed level of significance, the perceptions of officers and clerks regarding the favorable work environment in the bank are significantly different.

\subsection{Rewarding for Performance}

The mean values of perceptions of officers and clerks on reward for performance are 2.53 and 2.24 respectively. It implies that the officers have neutral opinion but clerks disagree to the statement. The chi square value is 11.3140 and the $p$ value based on 4 degrees of freedom is 0.0233 . Since it is less than the assumed level of significance i.e., 0.05 there is significant difference of opinions among officers and clerks in case of reward for good performance of employees.

\subsection{Need based Promotion}

The average of the perceptions in case of officers and clerks being 3.47 and 2.87 respectively reveal that both officers and clerks have neutral opinion in this case. The chi square value is 21.4310 and the $p$ value based on the 4 degrees of freedom is 0.0003 . Since the $p$ value is much lesser than 0.05 , it is inferred that the difference between the perceptions of officers and clerks regarding need based promotion is highly significant. 


\subsection{Evaluation of Potentiality}

The mean of perceptions is 3.33 in case of officers and 3.05 in case of clerks. This resembles that the majority of officers as well as clerks have neutral opinion in this case The chi-square in this case is 10.8720 and the $\mathrm{p}$ value at 4 degrees of freedom is 0.0280 . Since the $p$ value is lesser than 0.05 , the assumed level of significance, there is significant difference of opinions among the officers and the clerks in respect of evaluation of potentiality of employees for giving promotion.

\subsection{Career Development Opportunities}

The mean values of perceptions of officers and clerks on communication of career development information are 3.26 and 2.92 respectively. It implies that the opinions of employees of both cadres are neutral. The chi square value is 6.4642 and the $p$ value based on 4 degrees of freedom is 0.1671 . Since it is more than the assumed level of significance i.e., 0.05 there is no significant difference of opinions among officers and clerks about the providing of information regarding career development opportupities.

\subsection{Opportunity to Accept Challenges $U$}

The average perceptions of officers and clerks amount to 3.46 and 3.15 respectively. This shows that the majority of officers and clerks show the neutral attitude in this case. The chi square on these perceptions is 5.8633 and based on the this value and 4 degrees of freedom, the $p$ value is calculated as 0.2096 . Since the $p$ value is more than the 0.05 , the assumed level of significance, the difference of opinions among officers and clerks is not significant in case of giving opportunity to work in challenging environment.

\subsection{Fast Track Promotions}

From the average opinion of officers and clerks being 2.29 and 2.47, it can be inferred that officers as well as clerks claim that fast track promotions are not given to efficient employees. The chi-square in this case is 2.5914 and the $\mathrm{p}$ value calculated on the basis of 4 degrees of freedom is 0.6283 . The $p$ value is higher than the assumed level of significance, therefore, it is revealed that there is no significant difference of opinion among officers and clerks in respect of the fast track promotions to high performing employees to keep them motivated.

\subsection{Promotion, Performance and Achievement}

The mean of perceptions in case of officers and clerks being 2.46 and 2.39 imply that the officers and clerks claim that employees are not promoted in accordance with the performance with the job and achievement of organizational and individual goals. The chi square value is 13.6600 and the $p$ value based on the 4 degrees of freedom is 0.0085 . Since p value is lesser than 0.05 , the assumed level of significance, it is inferred that the perceptions among the officers and clerks in respect of promotion based on performance and achievement differ significantly.

\subsection{Seniority based Promotion}

The mean values of perceptions of officers and clerks on reward for performance are 3.66 and 3.55 respectively. It implies that the majority of officers as well as the clerks agree that employees are promoted on the basis of seniority. The chi square value is 0.06919 and the $p$ value based on 4 degrees of freedom is 0.9994 . Since it is more than the assumed level of significance i.e., 0.05 there is no significant difference of opinions among officers and clerks in case of seniority-based promotion.

\subsection{Time to Adjust with Promotion}

The mean values of perceptions of officers and clerks being 3.42 and 3.02 respectively indicate that both officers and clerks have neutral opinion. The chi square value is 12.0943 and the $p$ value based on 4 degrees of freedom is 0.0167 . Since the $p$ value is less than 0.05 , the assumed level of significance, there is significant difference in the perceptions of officers and clerks in case of the policy of allowing sufficient time to adjust with the promoted position.

\subsection{Need based Transfer}

The mean values of perceptions of officers and clerks being 3.94 and 3.67 respectively indicate that officers as well as clerks agree that employees are transferred according to the needs of the bank. The chi square value is 5.5192 and the $p$ value calculated at 4 degrees 
of freedom works out to be 0.2380 . Since, $\mathrm{p}$ value is more than 0.05 , the assumed level of significance, the officers and clerks do not have significant difference of opinions about the need-based training.

\subsection{Right Person at Right Place}

The mean values of perceptions of officers and clerks being 3.35 and 3.12 respectively indicate that officers and clerks have neutral opinion in this case. The chi square value is 8.7063 and the $p$ value calculated at 4 degrees of freedom works out to be 0.0689 . Since, $p$ value is more than 0.05 , the assumed level of significance, the officers and clerks do not have significant difference of opinions about the policy of transferring the employees to get right person at right place.

\subsection{Matching with Responsibility}

The mean values of perceptions of officers and clerks in this case are 2.51 and 2.43 respectively. It implies that the officers have neutral opinion but the clerks claim that there is no matching between salary and responsibility. The chi square yalue is 4.3352 and the $p$ value based on 4 degrees of freedom is 0.3625 . Since it is more than the assumed level of significance i.e., 0.05 . there is no significant difference of opinions among officers and clerks about the policy of matching salary with duty and responsibility.

\subsection{Incentives for Efficiency}

The mean values of perceptions of officers and clerks being 2.32 and 2.36 indicate that the officers as well as clerks believe that the efficient employees are not rewarded with incentives. The chi square value in this case is 19.3997 and the $p$ value based thereon at 4 degrees of freedom is 0.0007 . Since the $p$ value is much lesser than 0.05 , the assumed level of significance, the perceptions of officers and clerks in respect of incentives for efficient employees differ very significantly.

\subsection{Sufficient Retirement Benefits}

The mean values about perceptions of officers and clerks being 2.30 and 2.47 respectively. It indicates that majority of the officers and clerks believe that sufficient retirement benefits are not provided. The chi square value in this case is 4.0586 and the $p$ value based on 4 degrees of freedom is 0.398 . Since, $p$ value is higher than the assumed level of significance i.e., 0.05 , there is no significant difference in perceptions among officers and clerks in respect of the sufficiency of retirement benefits.

\section{Suggestions}

The urban co-operative banks are meant for fulfilling the social and economic objectives. The orientation of this sector is towards the socialism. Hence, the employees are at the centre of these banks. Hence, on the basis of the findings of this study, it is suggested, that the management should consider the opinion of employees in the preparation of HRD policy and it should be properly communicated to all the employees to gain their confidence. The banks need to follow systematic and reliable selection process so that bank gets the right person for right job. The banks need to assess the need for training of employees. The training for development of skills of employees should be conducted at local level or the employees should be sent to training institutions at various places. The training programme shouk aimat filling the competency gap of employees and it should bedirectly related to their job. While promoting the employees, the merit and experience should be considered along with the seniority. The banks should see that the employees are motivated by the promotion and transfer. The efficient employees should be rewarded and in case of transfer, the convenience of the employees should be considered. Proper job evaluation needs to be performed to fix the remuneration of employees. The performance appraisal should be adopted on quarterly basis so that the internal control becomes effective. The management should also consider the salary matching with the responsibility. The retirement benefits like, pension plans should be introduced by the banks for employees so that they get security after retirement. The management needs to build the strong bond between bank and the employees. For this purpose, the HRD policies need to be framed which help to achieve the objectives of urban cooperative banks and also satisfy the employees. There are many training organizations like Vaikunth Mehta 
National Institute of Co-operative Management, RBI College of Agricultural Banking, National Institute of Bank Management and State Co-operative Institutes in India. Nevertheless, it is suggested that the Central Government should establish district level training institutes for employees in co-operative education and prepare them for global competitiveness.

\section{Bibliography}

Krishnaveni, R., \& Deepa, R. (2011). Human Resource Management Practices in Coimbatore-with Special Reference to the Manufacturing Sector. Management Dynamics, 11.

Kumar, N. (2003). Motivation and Morale in Banking Administration. [Thesis], New Delhi: Indian Institute of Public Administration, Mittal Publications.

Omondi, G. O., Magutu, P. O., Onsongo, C. O., \& Abong, L. A. (2011). The Adoption of Strategic Human Resource Management Practices in Commercial Banks: The Process and Challenges in Kenya. Journal of Human Resource Management Research.
Parikshit, J., \& Anuj, S. (2012). Examining the HRD Practices in Indian PSUs (with special reference to IOC Mathura Refinefry). Management Insight, 8(2).

Purohit, S. (2013). A Study of the Changes in Human Resource Management Practices in LIC due to the Impact of Private Insurance Players. Prabandhan: Indian Journal of Management.

Shetty, S. G. (2011). Role of HRM in Value Creation with specific Reference to Co-operative Banks in Udupi District of Karnataka State. Journal on Banking Financial Services and Insurance Research, 1(8).

Singh, A. K. (2005). HRD Practices and Philosophy of Management in Indian Organizations. Vikalpa, 30(2).

Sivaprakasam, P. (1993). Personnel Management in Central Co-operative Banks in India- Policies and Practices. [Ph.D. Thesis], New Delhi: Gandhigram Rural Institute (Deemed University) Gandhigram, Kanishka Publishers.

Sonali, G. (2012). Reengineering HR to Retain Women in Workforce: An Empirical Study. Journal of Commerce and Management Thought, 4(2). ISSN 0975-623X(print)0976-478X(online)

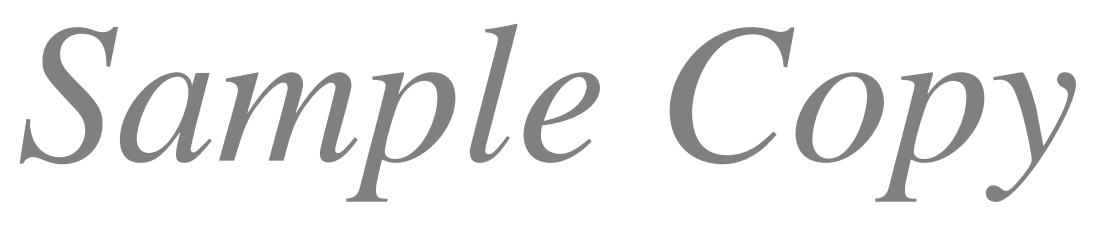




\section{BOOK REVIEW}

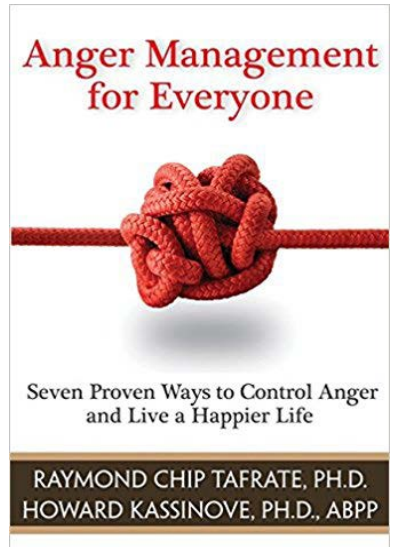

Anger Management for Everyone: Seven Proven Ways to Control Anger and Live a Happier Life by Ramond Chip Tafrate and Howard Kassinove

\section{Dr. Nilanjan Sengupta}

\author{
Reviewed by: \\ Publisher: Impact Publishers (31 Oct. 2016) \\ Paperback: 224 pages, Language: English \\ ISBN-10: 1886230838
}

ISBN-13: 978-1886230835
This book stands out as one of the best in its class especially when one looks at it from the perspective of a practising psychologist who straddle the twin worlds of business and the clinical realm. The book can give a lot of insight to a practising psychologist or a corporate trainer as well as executives in the corporate world who are compelled to deal with issues of their own aggression and the aggressive behaviours of their colleagues in demanding and competing situations that characterize today's business environment. Often counsellors and trainers are faced with issues while coaching executives who complain about becoming victims of their own aggression and anger and lose control or get stumped by reactions of colleagues and other organizational members who do not respect leadership, but comply due to fear of being reprimanded or other serious consequences where leaders can fire them and make them lose their jobs. Many a times the executives are not willing to take responsibility for their anger driven responses to pressures which inevitably is leashed out on other employees with less power and authority in the organizations. For such situations, this book comes as a boon since it provides answers to many of the above-mentioned problems which need to be addressed by professionals who are either counsellors or the leaders themselves desperately seeking solutions in anger management.

This book provides valuable insights about how to approach one's anger responses in two essential ways: one, it provides understanding of anger as a human emotion and also outlines seven ways in which anger can be managed/readiness to change one's anger patterns can be built up to live a more peaceful and controlled life. In other words, it is an excellent book and can serve as a tool for those who would want to become aware about how their anger affects them and those around them and how to change all of this to be a more adjusted, controlled and acceptable individual in the final analysis.

The structure of this book is its plus point. It has been divided into three parts essentially, and in each part, there are chapters which make a logical flow and creates ease of understanding as one travels through the pages of the book.

Part I: Anger Basics: This section is neatly broken up into 3 chapters and gives a clear understanding of various aspects related to anger.

Part II: Seven Proven Ways to Control Anger: The seven chapters in this section identify various strategies and tactics, and provides specific examples on how people can control their anger, effectively. The illustrated methods are also supplemented by worksheets that can be copied and used in a variety of situations where anger might surface up and become problematic for an individual.

Part III: Other Issues: This final section includes two chapters that can be seen as follow up steps for continuously maintaining their anger management techniques in order to retain control over anger at most times. 
Two chapters which deserve special mention in this book are chapter 7 on Forgiveness and Chapter 10 on Express Your Anger in an Assertive, Productive Way. While chapter 7 provides the illustrative benefits of 'forgiveness' a strategy and 'doing away with grudge', chapter 10 gives clear road signs and a path to productively convert negative energy and wastefulness to more productive usage of anger for getting positive results.
This book is, therefore, highly recommended for both therapeutic use by the professionals who counsel people in the area of anger management and need to provide specific guidelines in constructive anger management techniques and by those, who need to become more controlled individuals with regard to managing their anger, so as to learn how to unleash anger in a more desirable manner on their near and dear ones, and in their professional capacities in their workplaces.

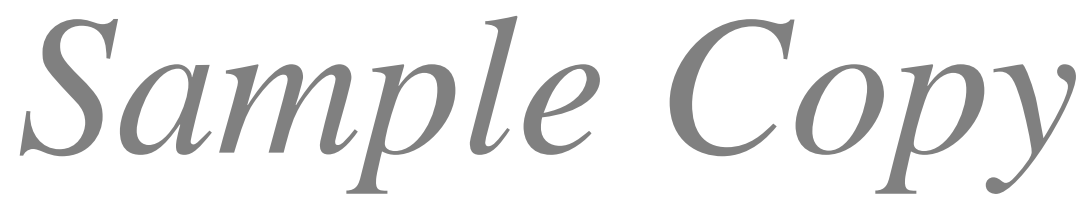

